\title{
Study on the Mobility in Status of Women Evolutionary Phases towards Empowerment in India
}

\section{Pradeep M. D.}

Assistant Professor, College of Social Sciences \& Humanities, Srinivas University, Mangaluru, Karnataka, India.

Email: mdpradeepnair767@gmail.com

Type of the Paper: Research Paper.

Type of Review: Peer Reviewed.

Indexed in: OpenAIRE.

DOI : http://doi.org/10.5281/zenodo.1462570.

Google Scholar Citation: IJMTS

\section{How to Cite this Paper:}

Pradeep M. D. (2018). Study on the Mobility in Status of Women Evolutionary Phases towards Empowerment in India. International Journal of Management, Technology, and Social Sciences (IJMTS), 3(2), 73-86. DOI : http://doi.org/10.5281/zenodo.1462570.

International Journal of Management, Technology, and Social Sciences (IJMTS)

A Refereed International Journal of Srinivas University, India.

(C) With Authors.

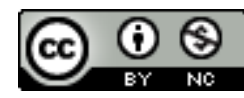

This work is licensed under a Creative Commons Attribution-Non Commercial 4.0 International License subject to proper citation to the publication source of the work.

Disclaimer: The scholarly papers as reviewed and published by the Srinivas Publications (S.P.), India are the views and opinions of their respective authors and are not the views or opinions of the SP. The SP disclaims of any harm or loss caused due to the published content to any party. 


\title{
Study on the Mobility in Status of Women Evolutionary Phases towards Empowerment in India
}

\author{
Pradeep M. D. \\ Assistant Professor, College of Social Sciences \& Humanities, Srinivas University, Mangaluru, \\ Karnataka, India. \\ Email: mdpradeepnair767@gmail.com
}

\begin{abstract}
Women are the embodiment of divine virtue and purity blessed with the sweetness of speech and beauty from the god. There were contradictory dialogues about women where some schools of thought representing them to be 'equals of men' and other schools trying to spread hatred and disrespect by projecting women to be weak minded and unworthy of trust. The status of women witnessed a steady shift along with the phases of Indian society since from ancient to modern times. The life of women was highly influenced by the social attitude and practices in light of philosophical ideologies. The ancient epics and literature placed women with the utmost respect and integrity. The sacred position granted to women found a shattered steady decay with the time leading towards disrespect and injustice. Women started to regain the lost status only in the later part of the nineteenth century. The study on the mobility in the status of women is possible only through a detailed review into the integrated evolutionary process of social system and practices. The injustice and deprivation caused due to the shattered status can be compensated only through equity and justice. Equity in status can be attained only through inclusive growth. This paper highlights on the issues connected to the mobility in the status of women along the ancient, medieval and modern era. It describes the efforts on women empowerment for inclusive growth to ensure equity among men and women thereby recapture the status to which women are deprived off.
\end{abstract}

Keywords: Women, Mobility in Status, Social Attitude, Society, Injustice, Empowerment, Equity.

\section{INTRODUCTION :}

The chronology of Hindu Orders started from Vedas, Brahmana (1500 BC-500 BC), Upanishad, Grihya Sutra, Dharmasastra and Epics (500 BC-500 AD), Smritis (500 AD-1800 $\mathrm{AD}$ ) and Puranas. Ancient literature placed women with the utmost respect and integrity. The ancient astronomer Varahamihira in his work 'Brihat Samhita' quoted about domestic relations that end pursuit for 'Dharma' denoting the righteousness and 'Artha' denoting the wealth in the society depends on women. Manu in his 'Manu Smrithi' quoted that such families will perish where women are living in grief and trouble and families keeping women happy will prosper. Male and female are complementary as
'Purusha' and 'Prakriti' even though they are bisexual by nature. The involvement of women during the early period is quoted in some of the famous works like the very old 'Bharhut Sculptures' mentions on horse women, 'Patanjali' mentions about 'Shaktikis' who are the spear bearers in the army, 'Megasthenes' in his book 'Indica' specifies about King Chandragupta had amazonian women as his body guards, Kautilya mentions in his 'Arthashastra' about women archers in the houses and forest. The 'Nalanda' and 'Thakshila' Universities used to educate women in fine arts of music, dancing and painting. Till Third B.C. the marriage was considered to be a ritual and marriageable age was sixteen. 'Manusmruthi' and 'The Dharmashastras' 
quoted about the doctrine of perpetual dependence of women on men by enunciating women as the fragile plant, to be cared and nourished by man. These are the proof for having absolute status by women equally with men. There were some schools of thought to protect the interest of women proposing for their freedom in marriage, inheritance and equal participation in public affairs. In contrary, some school of thought continued to spread disrespect on women by spreading ill thought that 'Women are burning fire and just illusion created by 'Daiya Maya' or devil and there is nothing more sinful than women and she is like the sharp edge of razor'. In Mahabharatha quotes are made about 'Draupathi Vasthra Apaharana' depicting disrespect on women. Ramayana incorporated that 'The faces of women are like flowers, words like drops of honey but their heart is like a sharp razor as their real feelings cannot be understood by anyone [1]. Gradually issues of inequality and discrimination on women emerged as a result of custom [2]. The occupation in the society is divided on gender. Girl children were entrusted with the works of weaving, stitching, domestic works, and cropping. Even though the above statements are done under a specific context, the real understanding of the status of women is possible by reviewing the life of women different periods.

\section{VEDIC PERIOD :}

The status of women during the Vedic period can be understood only by reviewing the freedom and restrictions they have faced in occupation, marriage, sacrifices and religious aspects. The Indian society was prevailed by the 'Chaturvarna System' based on division of labour and occupation. There were four types of 'Vernas' or 'Races' comprising Brahman, Kshathriyas, Vaishyas and Shudras. 'Brahmins' offer prayers and sacrifices to god, 'Kshathriyas' defend the country from the enemies, 'Vaishyas' engage in the business activities and 'Shudras' render services in the society. People believed that women are graced with special qualities of grace, tenderness, peace, affection, surrender and sacrifice. The dual role of women as wife and mother are undoubtedly important, highly skilled and difficult one. Brahmin girls were taught in Vedic wisdom whereas Kshathriya girls were taught to use bow and arrows. Marriage was considered to be the companionship between male and females to achieve the objects of life. Hindu marriage creates companionship between male and female who decide to live together and achieve Dharma, Artha, Kama and Moksha. The purpose of marital life was procreation, caring and nurturing of children and encouraging social participation. The husband and wife shall improve their personality and supplement each other to fulfill the needs of the life which leads them towards completeness. The 'Smritis' and 'Dharmashastras' quotes about eight forms of marriages. 'Brahma Vivah' was the most approved and popular form of marriage among all class where well decorated bride is offered to the bridegroom, who shall take the oath of closely associating with his wife in all spheres of life. 'Gandharva Vivah' was based on mutual consent of the lover and beloved. The 'Gandharva' unions will happen without recitation of mantras but ceremonies are performed after the union to seek social approval. Kalidasa's great drama 'Abhijnana Shakuntala' mentions about this form of marriage between 'Dushyanta and Shakuntala'. In 'Daiva' form of marriage the 'sacrificee' offers his daughter in marriage to the officiating priest. In 'Prajapatya' marriage the bride is offered to the bridegroom with due rites that couple are enjoined to be inseparable companions in discharging their religious duties. In 'Paisacha' marriage, any male marries a girl while she is asleep, unconscious and mad. In Rakshasa' marriage women are regarded as prizes of war. In 'Rigveda' instances of aryan masters purchasing slave girls sites examples for these type of marriage. In 'Asura' marriage, the husband buys the bride for a price, where father of the bride is permitted to accept a cow and a bull from the son-in-law. In Vedic society, The 'Paisacha', 'Raksasa' and 'Asura' marriages were considered to be the distorted forms of civilization as it deprives women from equality by reducing them to a sexual unit. The 'Brahma vivah' was considered to be the ideal form of 
marriage but there were some instanced of 'Gandharva' and 'Asura' forms of marriages also. Position of wife was honored religiously based on the existed belief that neither the husband nor wife could reach heaven without being accompanied by the other. The highest expression in religion was the sacrifice. Both prayers and sacrifices were jointly offered by husband and wife. The unmarried women who studied Vedas are known as 'Brahmavadini' who are allowed to perform rites. 'Sandyovadhu' are the women who perform the ceremony of 'Upanayana'. Single standard rule for both men and women that "Any wife who does not adhere to her husband will be considered sinful and committed a great and heinous sin as like killing of an embryo and the men who will go to other women, neglecting a loving wife who has observed from her youth the vow of chastity will commit the same sin" was prevalent in the society. There was a social acceptance for inter caste marriages in the Vedic society. Ancient literature like 'Rigveda' mentions about inter caste marriages. Chanakya in his 'Arthashasthra' said 'bride can be chosen from any caste or community even from low castes. Several inscriptions also quoted about instances where Hindu princes marrying foreign princesses. Manu writes that 'a man can marry a girl even from inferior or bad families if the girl lives the life of goodness'. 'Mahanirvana Tantra' specifies that in 'Daiva' form of marriage existed condition for marriage was only that women should not be falling within prohibited degree and have husband at the time of marriage. It justifies inter caste marriages and widow marriages by specifying that age and caste are not the barriers for marriage. 'Monogamy' was the cultural trait and considered ideal form of marital life since there was no infringement on the morality. This ideal form of marriages are replicated with the examples of marriages between 'Shiva and Parvati', 'Rama and Sita', 'Nala and Damayanthi', and 'Satyavan and Savitri'. 'Rigveda' specify the well established rule for marriage and do not specify anything about the practice of 'Sati' [3]. But 'Atharvaveda' gives clues about practice of 'Sati' as a custom where a widow shall lie by the side of her husband corpse on the funeral pyre. 'Manusmriti' prescribes the code of conduct giving sanction for the widow remarriage in the form of 'Niyoga', where a dead man's brother or next kin shall marry the widow as a custom [4]. Women had only secondary status with respect to economic capacity as they were not vested with major rights in this regard. Joint ownership of property by husband and wife was allowed but the complete right over property was vested only with the husband. Women had absolute right over the movable property especially on 'Ornaments' which was gradually considered as 'Stridhan'. Only sons were granted with the absolute right over paternal property whereas, daughters have no share in her father's property. Mothers property will be equally divided among sons and unmarried daughters. However, wife is entitled to one third share in her husband's property. Even though religiously women enjoyed fullest rights but politically their status was very weak as they were not given the right to vote [5]. To conclude, the women enjoyed freedom in selecting their mates, they were highly regarded while taking religious decisions, widows were allowed to remarry and divorce was not permitted in the society emphasizing most importance to marital relationships. Thus, in the beginning, the social position of women was just and fair with economic freedom to produce home based produces, wife will engage in agricultural activities along with their husband. The women were respected and placed in the highest esteem during Vedic period [6].

\section{LATER VEDIC PERIOD :}

The prevailing position of women with high respect and treatment of equity with men disappeared in the post Vedic period due to the emergence of number of subsidiary sciences, lengthy commentaries and religious texts. Along the changing society and culture, the position of women started to decline. Gradually male counterparts failed to recognize the merits of women in society. The instances of pre puberty marriages started to emerge and the sanction for the widow remarriage become unpopular during 300 B.C. to 200 A.D. 'Iberuni' quoted in his 
work about remarriage of widows was prohibited by the custom extending it even to child widows. Husband was projected to be the god for the wife. Manu in 'Manusmriti' propagated unfair practice by specifying that 'a good wife shall adore even to a bad husband as a personal duty giving rise to a new system of slavery by the wife towards husband. This exaggerated preaching attempted to justify the duty of devotion of wife towards the husband. 'Apastamba' has mentioned about the unkind practice of wearing the skin of donkey and beg for food. Differential treatment for widowers and widows started in the society. Widowers were permitted to remarry for performing his religious duties but, the presence of wife is not essentially required for such performances. 'Aitareya Brahmana' stated that a widower can perform his Vedic sacrifices even without wife with 'Sradha' or 'Devotion' which intern takes the place of wife. The education was denied to women and age of marriage was continued to be sixteen or seventeen. Most difficult laws were imposed on women encouraging ill practices like polyandry forms of marriages, the best example in this regard is 'Draupadi's' marriage with five brothers. Polygamy was prevailed among princes and noblemen. The 'Shastras' permitted husband to contract second marriage with the consent of his wife if she is found to be suffering from an incurable disease or adulterous. Legal sanction was provided for polygamy resulted in spreading unhappiness among the women folks. Women were denied with the property right with a popular social quote that 'a wife and slave cannot own property'. According to historians and scholars, women were totally denied with equality and tolerance due to the dominance of Brahmanism, restrictions imposed through caste system, joint family culture, lack of educational opportunities for women, and racial discrimination among Aryans and Non Aryans.

\section{ERA OF ANCIENT RELIGION :}

(i) Jainism: Jainism in common with Buddhism rejected the sanctity of the Vedas, superiority of Brahmins, the sacramental notion of marriage considering sex relation out of wedlock to be inferior to celibacy. Jain preachers propagated 'Ascetiscism' and 'Ahimsa' by insisting non killing. From the times of 'Parasvantha' down to the present, women were admitted to the religious order of nuns. There were few differences in the title to liberation among 'Digambaras' and 'Shwethambaras'. The 'Shwethambaras' in supporting their contention asserted that Malli a lady is the nineteenth thirthankara which 'Digambaras' reject with contempt. Digambaras further maintained that nudity is absolutely essential for perfection while the other sect hold that, no harm can happen to the soul by wearing white garments. The 'Digambaras' admit about the difficulty of women nuns to appear in public without cloths making it a reason to show case incompetency of women from salvation. Jain philosophy does not believe that marriage have indissoluble ties hence, men can choose to leave their wives at any time for taking monastic life. In the earlier stages even women were also given the freedom to leave their husband for choosing a monastic life. Jainism considers nuns to be inferior to monks in the monistic life hence, they were prohibited to study chapters of 'Mahaparijnana', 'Arunopapta' and 'Drshtivada'. As women were generally considered as not strong and fickle, they were not allowed to study scripture like 'Drshtivada' dealing with magical formulate. The inferior status provided to Nuns in the society is clearly reflected in the general monistic rule that 'A Monk of three years can become a teacher of a Nun who is of thirty years'. Adultery was punished with severity except in the cases of Nuns. Since there were no regular convents for Jain's Nuns were forced to lead a wondering life. The unprotected life made Nuns the victims of Seduction, Molestation and Rape. The children born due to atrocities against women shall not be condemned. The Jain text 'Brihat Kalpa Bhasya' quotes about the possibility of pregnancy without actual sexual intercourse due to four reasons namely sitting without cover at a place smeared with semen, introduction of semen into the genitals of sleeping women by the desired person, using garment stained with semen during her 'Rutu' and drinking of water containing semen by a 
woman. The Jain Canon clears that, mere fact of pregnancy should be taken as a proof for guilt and any pregnant Nun shall not be turned out of the Order [7]. Any offenders in this regard shall be punished but in other cases, the victims shall be protected from slander and condemn by supporting her to live in the house of any respectable householder or at 'Upasraya' the homes meant for nuns, where she should not be allowed to go for begging alms which is her daily religious duty until her delivery. Such instances are reported in the cases of 'Kesi' and 'Satyaki' who were born to nuns without being guilty. This tolerance and humanitarian attitude proposed by the Jainism was in contrast with the cruelty committed by the later Hinduism, where unmarried women or widows found with child were excommunicated or abandoned. Adultery was not punishable under all circumstances equally. Jain monks enjoyed certain privileges against adultery, as people believed that learned monks are capable to producing geniuses in dull women and intercourse with a strictly celibate monk will cure sterility in women. The Jain text 'Acharanga' mentions instances of monks living as guests with wives, daughters, daughter-inlaw, and slave girls of house holders who have often approached the holy men for cure of sterility or for obtaining illustrious sons [8]. Prostitutes believed in the efficacy of physical contract with monks to remove spiritual impurities. The practice of Child Marriage was a fashion among the Jains. The practice of sati was confined to certain clans resulting in the survival of some women after the death of their husband and others immolated themselves in the funeral pyres of their husband. Kings during this time considered women as one among the fourteen jewels of royalty, hence loved to display their splendor through the number and quality of women they possess. Some sort of 'Purdah' system was observed by the ladies of royal clans as they did not wish to be seen by the vulgar eyes. Jain's held mother in the greatest esteem [9].

(ii) Buddhism: Buddhism and Jainism were the contemporaries hailed from east India founded by 'Kshatriyas' lived in the sixth century before Christ. The conversion of the mauryan emperor
'Ashoka' to Buddhism made it the most important religion in the whole Asia. From the time of Ashoka to the rise of Islam, Buddhism was reckoned in all countries in the east of Persia as the religion of civilized mankind. In Buddhist society, wife occupied equal position with the husband. It considers both sexes are equally useful to the society in spite of their biological and physical differences. Buddha emphasized on the fruitful role of women as wife and mother in making the family life. Both husband and wives share equal responsibility in the family. Husband considers the wife as a friend, companion and a partner for life. Wife shall substitute husband in the family affairs if husband happened to be indisposed. Wife shall acquaint with her husband's trade, occupation and business so as to manage his affairs in his absence. The birth of a daughter is not considered to be the reason for worry or respire. It does not restrict educational opportunities or religious freedom for women. The Buddha accepted that women can realize the truth as like men hence he permitted their admission into the order and placed with responsibility under 'Bhikkhuni Sangh'. The stanzas in the text 'Therigatha' mentions about 'Saint Bhikkhunis' by name 'Dhammadinna', 'Khema' and 'Uppalayanna' who preached Dharma and experienced the joy of entering the Order and realized the Truth.

(iii) Islam: The Noble Quran honors women and treats her with justice. Islam considers the woman as a worthy human being having a share in humanity equally with the man. They are granted with the right of inheritance along with the powers to sell, buy, rent, donate, transfer, pledge, mortgage etc. Islam guarantees the right to seek education by making it incumbent on women to seek knowledge. The women shall perform all religious ordinances in the form of praying, fasting, zakat, pilgrimage as responsible humans. Allah assigns guardianship of women to the man by virtue of Quran. Abu Hanfa quoted that, women are not forbidden from positions in the judiciary which falls within the sphere of testimony. The blood money or 'Diya' payable in cases of accidental homicides are equal for men and women. Men shall protect and 
maintain women in the family. According to Abu Hanfa, women were not forbidden from occupying positions in the judiciary to decide matters except criminal affairs. Islam permits the women to wear gold and pure silk to stream tenderness and beauty among them. The religion protects the morals, decency, reputation and dignity of women by preserving decent, unrevealing pattern of dress and ornamentation. Women are not deprived of her right to participate in serving her community on the condition that she observes the limit of the Islamic code in social life. In social life, the muslim women plays the role of preaching of good ideas enjoying the right and forbidding evil. The Prophet said "the world is delightful and its greatest treasure is a good woman". Marriage is essentially a civil contract creating economic obligation on the husband made in clear terms in the presence of two males or one male \& two female witnesses who are adults with sound mind. The women are entitled to claim 'Mahr' which is the obligatory bridal money given by the husband in good heart as a gift and not as a price at the time of marriage in proportion to his financial ability. It is unlawful to ask back the 'Mahr' from the wife by the husband at any time. A man cannot have more than four wives at a time. The husband shall provide his wife with food, cloths, place to live and medical support according to his conditions and income. Women are granted with the right to live with honour a collective right guarantees good treatment in all aspects of the marital relationships with good manners, flexible attitude, sweet words, smiling face, pleasing playfulness and amusing mien etc. Islam provides distinctive personality for married women by sanctioning civil rights to sell, buy, rent, give charity and sue or be sued. Muslim law entrust a wife with the duties of residing in the house of her husband, obedience to his reasonable orders, performing her marital functions as required by the husband with due regard to health and decency, observing strict conjugal fidelity, refraining from undue familiarity with strangers and unnecessary public appearance. Among Shia's muta marriages is prevalent where, a couple marries for a stipulated period after which the marriage becomes null and void without any divorce proceedings. If the aversion between husband and wife has undiminished and the attempts for reconciling the parties fail to bring them together can seek for the bitter medicine called divorce. Abu Al-Tayyeb Al-Mutanaby quoted that it is a great calamity to live with someone who do not agree with you but does not leave you. Islam however, does not decree divorce at all times, it is permissible according to Qur'an and the Sunna (Prophetic Traditions). For instance, husband should not divorce his wife during her menstrual period, until she has completed her next menstrual period when she is purified of her menses if he had intercourse with her to ensure that she is not pregnant. The man should be in a well balanced and judicious state. The divorce granted when he is not fully conscious or forced or in a state of wrath which causes him to go beyond his intention it is not considered valid. Divorce can be given at the will of the husband without any legal proceedings by repeating the word 'Talak' three times. However, divorce does not completely cut off the marriage tie and makes it irremediable, on contrary, every divorced man gets two chances to go back and redeem the situation making the third divorce to be decisive. After which divorce cannot return to him unless she marries to another man. Divorce does not deprive the divorced women from seeking maintenance during the legislated period for which she stays without marriage. 'Iddah' is a waiting period where a divorced woman is not free to marry anyone else until she gives birth if she is pregnant or three menstrual cycles when under regular periods or three calendar months when she does not have menses. After divorce she can marry anyone else or may go back to her divorced man with a new marriage contract and new dower. The divorced women have the right of 'Muta' a compensation or gift made in lump sum and for maintenance on reasonable scale. It is forbidden for the divorced man to spread rumors about his ex wife or to scandalize her or offend her or her family after divorce. Women are equal heir in the property. The son cannot exclude a daughter from a share in the father's 
property. Marriage does not give the husband any rights over the property of his wife during her lifetime, which she can administer in her own right and even alienate without the permission of the husband. In earlier days of Islam, women were free to visit the mosque and prey but the practice was, later condemned as good men found it difficult to concentrate on prayers in the presence of women, by the third century in the Muslim era, this system fell into disuse. The 'Pardha' became popular among upper classes. Royal and Aristocratic households enjoyed extensive pleasure parks, sports and education from the lady instructors. But women from middle classes were anemic and victims of many physical ailments. Within middle class households, 'purdah'was not strictly practiced they could appear without the veil before friends and relatives and converse freely with them. The Muslim conquest, caused large scale immolation of women especially Rajputs who considered that it to be lesser evil than captured by the invaders. The Muslims with their secular notions were against the institution of Sati and discouraged it among the Hindus whom they have ruled but due to many reasons they could not stop it. By the time when the Muslim rule was well established in India, Sati was practiced among the Hindus with the sanction of tradition. The later Muslims, found it difficult to rule the country without the cooperation of the Hindus hence they were reluctant to interfere in the religious observances of the people. Hence, even though many Muslim rulers tried to abolish Sati in their rule, the practice flourished without many hindrances.

\section{MEDIEVAL PERIOD :}

During this period until the advent of British rule in India status of women found several changes. Even though Indian society recognized the right of widows in her husband's property during 900 A.D. to 1200 A.D. their status deteriorated in other fields due to the reduction of education to the age of eight and sanction on widow marriage disappeared by the end of 500 A.D. from the social scene. The 'Mughal' age introduced new customs and traditions in the form of 'Purdah' system. Ramanujacharya introduced 'Bhakti Movement' during $15^{\text {th }}$ Century orienting some changes in the social and religious rights of women in India. The Bhaktas like Chaitanya, Guru Nanak, Meera, Kabir, Ramdas stood for the right of women. In order to free women from the existing social maladies, the movement argued for social and religious rights of women. Women education was emphasized with the encouragement of women to read religious books. It protected the interest of women by prohibiting saints from choosing 'Sanyas' without the consent of the wife. Since the economic rights of women were untouched, the women continued to hold low status in the society during this period [10].

\section{BRITISH REGIME :}

India records only invisible progress in the status of women during the British rule of 200 years since $18^{\text {th }}$ Century. The emergence of Christianity is rooted with the establishment of colonial rule by British in India. Initially Apostle Thomas built churches and started to preach Christianity in the south Indian and later the religion was established under the authority of church. The Biblical doctrines sought complete commitment of the believers towards spirituality throughout their lives. During the period of old testament women were deprived off social status. Women were pushed to the status of subservient by socially, economically and religiously confining them within the hands of men. But Jesus gave equal status to women in the new Testament by elevating the status of women from margin to the centre [11]. The writings of Felicity, Perpetua and Blandina reflected the feminist thought seeking women positions in the church and bold move against the resistance of men on their liberty. During $16^{\text {th }}$ Century, The Roman Catholic Church engaged in Evangelic work in India. The Protestant Christianity was popularized with the activities of German Lutherans during $18^{\text {th }}$ Century. Christianity granted equal status to Men and Women and placed Christian women in better status compared to women from other communities. They were allowed to travel independently, engage in occupation, business and other activities on par with men. Christianity 
prohibits Child marriage and supported Monogamy to ensure better care and respect for women. Will of the women was considered important to create marital relationship. Girls were allowed to choose their life partners from within their community. Women are vested with the right over property including the rights to sell, transfer and making any type of contracts on it. She is allowed to work and lead independent life. Christian women play the role of a sailor in the family affairs along with her husband without confining herself to four walls of house. Absolute political rights in terms of right to cast the vote, contest in the elections were also granted. They are given almost equal religious rights on par with men like reading Bible, attending prayers along with men folk, visiting church, take part in religious activities, choose to become nuns and dedicate themselves for the cause of the religion. Western missionaries tried to influence conversion of Indian women in order to protect them from the social inequalities and practices of the Indian society. The activities of the missionary significantly raised the status of women by providing opportunities in many organizations, missionaries and charitable activities. Missionaries initiated formal and informal education for women paving destitute women and miserable widows to find new ways of life to escape from the unjust practices of society. The Missionaries established first girls' school under the initiative of Lord Dalhousie in 1824. The girls were prohibited from University education until 1875. The Hunter Commission recommended for women education in 1882 . Some substantial progress was achieved by eliminating the inequalities among men and women in education. The prevailing Social evils including Sati, ill-treatment of Widows, Ban on Widow Remarriage, Polygamy, Child Marriage, Denial of Property Rights and Education to women attracted social reformers. The Social Reformers felt the need for eradication of these evils by raising consciousness and creating awareness on injustice among women. The strongly believed that women education and enactment of progressive legislation can definitely bring social change. The Social
Reformers including Raja Ram Mohan Roy, Ishwarchand Vidyasagar, M.G. Ranade, Mahatma Phule, Lokhitwadi raised voice against the unjust practices against women. Dayandand Saraswati, Swami Vivekananda and Annie Beasant presumed in building an ideal society by reviving the old Vedic society. Women got an opportunity to come to the forefront during $19^{\text {th }}$ Century through 'Social Reform Movements' under the leadership of stalwarts Raja Ram Mohan Roy, Ishwarchand Vidyasagar \& Jyotirao Phule. Social reformers like Justice Ranade \&Raja Ram Mohan Roy tried to abolish ill practices such as Sati, Purdhaetc. Ishwarchand Vidyasagar launched a movement for the right of widow remarriage and pleaded for women education. Maharaja Sayajirao Gaekwad of Baroda fought against child marriage, polygamy, women education and widow remarriages. Many reformatory measures and laws were initiated during the period. Bengal Sati Regulation Act 1829 was passed declaring the practice of sati as illegal making it to be an punishable offence. Hindu Widow's Remarriage Act 1859 was passed. The Indian Penal Code 1860 was enacted to provide punishment for the offences of abduction, rape, bigamy etc. against women. Indian Divorce Act, 1869 was enacted to grant divorce for the Christian Wife on the grounds of adultery, cruelty, desertion etc. The Married Women's Property Act 1874 declared that any property purchased by women through employing her art and skill or by spending her savings or investments shall be her separate property [12]. The Social Reform Movement awakened social consciousness and granted liberation for women against social evils and granted equal rights to women in the society [13]. The Social Reform Movement has built intellectual capacity among Indians to move towards the 'Indian National Movement'. Bharath Mahila Parishad an womens organisation was founded in 1904 to represent the needs of women. Women freedom fighters showed immense courage to fight against British during 1905. Bharat Stri Mahamandal founded was founded in 1910. SNDT Women's University was established at Maharastra by Maharshi Karve in 1916. Annie 
Besand started Womens Indian Association in 1917. The 'Swadeshi Movement' of 1920's encouraged women from traditional families to come out of home and raise voice against oppression including caste and clan prejudices [14]. The Nationalist Movement helped the women to organize themselves to fight for their own cause rather depending on the benevolent men for the undue help. Prior to Independence, awareness on social disabilities was created by encouraging women education. Indian Succession Act, 1925 grants intestate and testamentary succession rights over the property to women as like men. All India Women's Conference 1927 lead women to march for equality [15]. The Child Marriage Restraint Act 1929 prohibits marriage below the age of 14 years. The History always recognizes the large scale participation of women in the 'Nationalist Movement' lead by Mahatma Gandhi Especially in the Civil Disobedience Movement 1930 and Quit India Movement 1942 in spite of the arrest of many women. Some participated in the Revolutionary Movement as couriers to distribute literature risking themselves from police repression, imprisonment and capital punishments. Women Volunteer Force in the name of 'NariBahini' was started to guard villages at night. The Gandhian era created powerful platform to improve the position of women. Gandhiji by keeping immense faith on the strength and morality of women criticized the practice of Child Marriage, Prohibition of Widow Remarriage, Temple Prostitution and Purdha. He planned for an organized mass movement with Khadi. It has united village spinners with urban families. He encouraged women to support 'Swadeshi' to cultivate the habit of new ways of life. National Council of Women was founded by lady Aberden \& Lady Tata. The Muslim Marriage Act, 1939 granted right to divorce. Women participated in 'Tebhaga Movement' (1946-51) for land reform in Bengal. Reinforcement in education was initiated during $19^{\text {th }}$ Century by establishing Fort William College, The Hindu College in Calcutta and Sanskrit College at Banaras. Along with the rise in understanding of women's problems, the evil practices of child marriage, polygamy, sale of girls, exploitation etc. was prevailing under the cover of religion.

\section{POST INDEPENDENCE PERIOD :}

The first law minister Dr. Ambedkar initiated legislative safeguards in the form of introducing Hindu Code Bill emphasizing for equal rights and social advancement of women [16]. The Republic governed in accordance with the Constitution of India was adopted and enacted by the Constituent Assembly on $26^{\text {th }}$ November, 1949 and came into force on $26^{\text {th }}$ January, 1950. The Preamble of the Constitution declared India to be 'Sovereign, Democratic and Republic'. The words 'Secular' and 'Socialist' were added through the $42^{\text {nd }}$ Amendment. The Constitution secure to its citizens Justice in social, economic and political, Liberty of thought, expression, belief, faith and worship, equality of status and opportunity among all, fraternity in terms of assuring the dignity of the individual and unity and integrity of the Nation. The law of the land granted Fundamental Rights to all the citizens including women which are justifiable. The Directive Principles of State Policy the guidelines to achieve the goal of welfare State. This period emphasized on labour welfare by enacting The Factories Act, 1948, The Employee State Insurance Act, 1948 focusing on the health, safety and welfare of the working class. The Government of India constituted Central Social Welfare Board in 1953 by launching a Nationwide Programme on Grant in Aid to promote welfare and developmental services for women, children and under privileged sections. The Special Marriage Act, 1954 permitted members of two different religions to marry without renouncing their religion. The Hindu Marriage Act, 1955 granted the Conjugal rights to protect the matrimonial life of women by enforcing monogamy on the male and granting right to divorce on the grounds of adultery, desertion, cruelty, insanity or incurable diseases. The Immoral Traffic Prevention Act, 1956 was enacted to protect women against trafficking [17]. Hindu Adoption \& Maintenance Act, 1956 entitling the Hindu wife with the right of maintenance. The Hindu Succession Act 1956 granted women with 
absolute right in property by abolishing the concept of limited estate. The Widow Remarriage Act, 1956 allowed the widows to remarry. The Dowry Prohibition Act, 1961 was passed to curb the practice of making request, payment or acceptance of a dowry as consideration for marriage [18]. The Medical Termination of Pregnancy Act 1971 was enacted to prescribe liberal grounds for safe, scientific and legal abortions. Participation of Women in 'Chipko Movement' 1972-74 proved the possibility of social action by the rural participatory organizations to pressurize elites like power brokers, contractors etc. The Equal Remuneration Act 1976 provides for equal remuneration to both men and women to prevent discrimination on the ground of sex. India ratified to the convention of Elimination of all forms of Discrimination against women 1981. The Indecent Representation of Women (Prohibition) Act, 1986 was enacted to prohibit the acts of indecent representation through advertisements. The Commission of Sati (Prevention) Act, 1987 prevents the practice \& glorification of Sati by declaring it to be punishable offence. In 1990s the employment opportunities in industries was made opened to women. The $73^{\text {rd }}$ and $74^{\text {th }}$ Constitutional Amendment Act, 1993 provided 33.3\% reservation to the women belonging to Scheduled Castes and Tribes in Panchayat Raj Institutions. The Pre-Natal Diagnostic Techniques (Regulation and Prevention of Misuse) Act, 1994 prohibits misuse of pre-natal diagnostic techniques for determination of sex and female infanticide. The Constitution (Eighty sixth amendment) Act, 2002 inserted Article 21A into the Constitution to provide free and compulsory education to all children between the age group of 6 to 14 years as a Fundamental Right. National Rural Health Mission was constituted in 2005 to target the health need of States having weak public health indicator. The Protection of Women from Domestic Violence Act, 2005 considers domestic violence as public health issue and grants Civil Remedy. The Prohibition of Child Marriage Act, 2006 pronounces enhanced punishments for violation. The Right of Children to Free and Compulsory
Education Act was passed in 2010. Nai Roshni scheme for Leadership Development was initiated during 2012-13 to empower Minority Women belongs to muslim, sikh, Christian, Buddhist and parsi religions. The Sexual Harassment of Women at Workplace (Prevention, Prohibition and Redressal) Act, 2013 vests the liability of providing safe working environment to women with the employer. The act covers the instances of preferential treatment affecting the health or safety, sexually determined behavior and unwelcome physical, verbal or nonverbal conduct of sexual nature under Sexual Harrassement [19]. Swachh Bharath Mission 2014 aims at achieving open defection free India by 2019. Pradhan Mantri Jan Dhan Yojana facilitated common man to open zero balance bank accounts. In 2015 Pradhan Mantri Suraksha Bima Yojana \& Pradhan Mantri Jeevan Jyoti Bima Yojana were introduced as the government supported social security schemes. National Skill Development Mission was constituted. Skill development initiatives like National Policy for Skill Development and Entrepreneurship 2015 and Pradhan Mantri Kaushal Vikas Yojana schemes were initiated. The Government of India under the leadership of Prime Minister Sri. Narendra Modi entered MoU on Cooperation between the Ministry of Youth Affairs and Sports of India and French Ministry of Sports, Youth Affairs, Public Education and Community Life in 2015 to envisage cooperation and exchange in sports based on the French model of INSEP. Beti Bachao Beti Padhao scheme 2016 was introduced to prevent gender biased sex selection in the 100 gender critical districts to ensure the protection and education of girl child. Pradhan Mantri Ujjwala Yojana, 2016 was launched to provide 5 Crore free LPG connections in the name of women households belonging to BPL families. Micro Units Development and Refinance Agency Bank (MUDRA Bank) was constituted for development of micro units and refinance micro finance institution to encourage entrepreneurship in India. Twelfth Five year Plan (2012-2017) concentrates towards creating structural and institutional mechanisms for women 
empowerment. Self Help Group Movement is an effective means for empowerment of rural women, building solidarity and socio-economic welfare of the poor [20]. The micro credit promotes quality of life by reducing the poverty considerably [21].

\section{CONCLUSION :}

As women were restrained only to the domestic responsibilities of bringing fuel, fodder and water they are unable to be a partner in the national growth [22]. It is essential to provide preferential treatment and special considerations to the deprived and disadvantageous sections. Women and Children constituted weaker section that deserves special considerations in every aspect of life. Since from the inception of Constitution, lot of reformatory measures were initiated concerning women. The depletion of women status has started to regain during the later part of $19^{\text {th }}$ Century along with the encouragement for women education. The Ministry of Women and Child Development in association with Ministry of Human Resource Development, Government of India jointly instructed the Universities to implement 'Gender Champions' to recognize the leadership among women by 2015. Women folk started raising voices against the inequality, patriarchic values and traditions. The Constitution granted cultural, economic and political rights to women. Government of India until 1970s adopted the philosophy of 'Promotion of Women Welfare', 1980s it aimed at 'Development of Women', during 1990s it aimed at 'Empowerment of Women' and after 2017 it is focusing towards 'Women Lead Empowerment' in the country. Law is bound by its cohesiveness based on the sources of authority, enforcement through sanctions and social acceptance [23]. Women welfare was intensively carried through Women Welfare Organisations like Young Women Christian Association, National Commission for Women, Inner Wheel (Women's section of the Rotary International), NGOs and associations like Mahila Mandals, Mahila Samiti, Recreation Clubs etc. Since 2010, the Judiciary have become hyper active in the matters connected to women by provide gender sensitive decisions.
The Bombay High Court lifted the four Century old ban on women entry into the Sanctum Sanctorum of Shani Shingnapur Temple, Nevasa Taluk of Ahmednagar District in Maharashtra [24]. Recently, The Supreme Court on $25^{\text {th }}$ April, 2016 directed Maharashtra Government not to restrain the owners from restarting dance bars but to make rules to regulate the performance of dance bars to protect the dignity of women by preventing obscene performances. It also held that, any regulation cannot enter the realm of prohibition. The dignity of women has to be protected but not by banning a profession unless it is obscene. It also cleared that women have the fundamental right to perform. It is better for the women to perform in dance bars than begging on the streets or indulge in some objectionable activities for life [25]. Supreme Court allowed women irrespective of their age to enter Kerala's Sabarimala Temple struck down the Kerala Hindu Places of Public Worship (Authorisation of Entry) Rules, 1965 which banned women between the age of 10 and 50 from entering the temple since centuries [26]. In the $21^{\text {st }}$ Century India aims to attain Gender Equity by granting equal rights to women in all spheres of life by eliminating discrimination based on caste and gender and encouraging them to contribute their share towards economic development of the country. Political empowerment is only a part in the process of overall mainstreaming of women, where the greater importance has to be provided towards economic and social empowerment of women [27]. The legislative measures should guarantee dignified life to women with the aid of Social Justice Programming. It shall try to protect the bodily integrity and personal autonomy of women through special considerations, affirmative action's, and reservation in education, employment and political life to bring gender equity in the society [28]. In consideration to the contributions made by the women at large, world recognized $1975^{\text {th }}$ year as the International year of women and announced to celebrate $8^{\text {th }}$ March as the 'International Women's Day'. 1991-2000 decade was considered to be the 'SAARC Decade of Girl Child and 2001 was declared to be the year of 
women empowerment. Gender sensitive public finance, trade, fiscal policies and extensive reforms in the judicial mechanisms for responsive administration of justice need to be focused in future days [29]. Women have now occupied the offices as doctors, engineers, CAs, Politicians, Advocates, Actress, Engineers, Teachers etc. On $19^{\text {th }}$ June, 2016, Avami Chaturvedi, Bhawana Kanth and Mohana Singh cadets of Dundigal Air Force Academy created history by becoming first Commissioned female fighter pilots in the country [30]. Still Women have a very long way to go.

\section{REFERENCES}

[1] Altekar A.S. (1938). The position of Women in Hindu Civilisation from Prehistoric Times to the Present Day. Culture Publication House, Benares Hindu University, 407.

[2] Indra M.A. (1940). The Status of Women in Ancient India.The Minerva Bookshop, Anarkali, Lahore, 12-13.

[3] Krishna Chandra Pradhan (2008). Rural Women Issues and Options. Sonali Publications, New Delhi, 01-04.

[4] Neera Desai \& Maithreyi Krishnaraj (1987). Women \& Society in India. Ajanta Publications, New Delhi, 35.

[5] Radha Kumud Mukherjee (1969). Ancient Indian Education (Brahmanical and Buddhist). Motilal Banasidass Publishers, Delhi, $4^{\text {nd }}($ Ed), p. 26.

[6] Gurudath C.A. (2006). Women, Child, Law and Society. Hindu Jurisprudence in Feminist Perspectives, Essay, Vidyavardhaka Law College, Mysore, March.

[7] Bhadrabahu. B. (1936). BrihatKalpa Sutra \& Original Niyukti of Bhadrabahu and a Bhashya. by Sanghadas Gani, Kshamashramana, Bhavnagar, Shri Atmanand Jain Sabha.

[8] Bhagwan Mahavira's Precepts- Agama an Introduction Festival (2012), English
Translation, Global Jain Aagam Mission, Mumbai, 7.

[9] Vijay Kaushik \& Bela Rani Sharma (1998). 'Encyclopaedia of Human Rights \& Women's Development', Indian Women through Ages, Sarup \& Sons, New Delhi, 59-75.

[10] Kakolee Chakraborthy (2000). Women as Devadasis- Origin and Growth of the Devadasi Profession. Deep \& Deep Publications Pvt. Ltd, New Delhi, 6-7.

[11] Jamieson, Penny. (1997).Living at the Edge: Sacrament and Solidarity in Leadership. Mowbray, London, 9.

[12] Diwan Paras \& Diwan Peeyushi (1994). Women and Legal Protection. Deep \& Deep Publications, New Delhi p. 260-262.

[13] Report of the Committee on the Status of Women in India (1974), Government of India, New Delhi.

[14] Indu Prakash Singh (1991). Indian Women: The Power Trapped. Galaxy Publications, New Delhi, 4.

[15] Neera Desai \& Maithreyi Krishnaraj (1987). Women \& Society in India. Ajanta Publication, New Delhi, 35.

[16] Kuber W.N (1979). Dr. Ambedkar: A Critical Study. Peoples Publishing House, New Delhi, p. 21.

[17] Bare Act on The Immoral Traffic (Prevention) Act, 1956 (1999). Universal Law Publishing Co. Pvt Ltd.

[18] Achar M.R. \&Vekannas T., (1961). Dowry Prohibition Act and Rules. The Law Book Co, Allahabad.

[19] MacKinnon \& Catherine, (1979). Sexual Harassment of Working Women. New Haven, Conn, Yale University Press, pp. 87-90.

[20] Pradeep M. D. (2017). Women Empowerment for Inclusive Growth. Studium Press Pvt. Ltd, New Delhi, p. 222. 
[21] Pradeep M.D. \& Rakshitha Rai R.P., (2016). Women Empowerment through Self Help Groups-Interventions towards SocioEconomic Welfare. International Journal of Management, IT \& Engineering, 06 (1), 424-441.

[22] Mohammad Noor \& Shahid Mohammad. (2004). Rethinking of Women Participation, Empowerment \& Gender Equality. Women's Link, 10 (3), 7-12.

[23] Shukla V.N. \& Mahendra Prasad Singh (2007). Shukla's Constitution of India. Eastern Book Company, Lucknow, $10^{\text {th }}$ (Ed.), 451-52.

[24] Deccan Herald (2016). Mangaluru, 19 (199), Sunday, April, 10.

[25] Amit Anand Choudhary (2016). 'Times of India', $26^{\text {th }}$ April.

[26] Indian Express (2018). 'Web Desk', September, 28'.

[27] Pradeep M.D. (2016). Legal and Policy Framework on women welfare: An inclusive Growth Strategy. Pearl Multidisciplinary Bi Annual Research Journal, 2 (1), 08-18.

[28] Pradeep M.D. (2015). A Study on Social Justice to Women through Judicial Activism In India. Deeksha, Bi-annual Journal of Social Work, 13 (1), 63-76.

[29] Pradeep M.D. \& Deeksha. (2016). MultiDimensional approach for empowermentEffective strategies to face problems and challenges of women in India. International Journal of Scientific Research \& Modern Education (IJSRME), 1(1), 744-755.

[30] Pradeep M. D., Ravindra B. K. (2017). Review on the Gender Sensitive Women Education-Legal Revolution in Higher Education. International Journal of Management, Technology, and Social Sciences (IJMTS),2(1), 53-65. 